\title{
Preservation and fermentation: past, present and future
}

\author{
R. Paul Ross ${ }^{\mathrm{a}, *}$, S. Morgan ${ }^{\mathrm{a}}$, C. Hill ${ }^{\mathrm{b}}$ \\ ${ }^{a}$ Teagasc, Dairy Products Research Centre, Moorepark, Fermoy, Co. Cork, Ireland \\ ${ }^{\mathrm{b}}$ Department of Microbiology, University College, Cork, Ireland
}

Received 21 March 2002; received in revised form 12 April 2002; accepted 16 April 2002

\begin{abstract}
Preservation of food and beverages resulting from fermentation has been an effective form of extending the shelf-life of foods for millennia. Traditionally, foods were preserved through naturally occurring fermentations, however, modern large scale production generally now exploits the use of defined strain starter systems to ensure consistency and quality in the final product. This review will mainly focus on the use of lactic acid bacteria (LAB) for food improvement, given their extensive application in a wide range of fermented foods. These microorganisms can produce a wide variety of antagonistic primary and secondary metabolites including organic acids, diacetyl, $\mathrm{CO}_{2}$ and even antibiotics such as reuterocyclin produced by Lactobacillus reuteri. In addition, members of the group can also produce a wide range of bacteriocins, some of which have activity against food pathogens such as Listeria monocytogenes and Clostridium botulinum. Indeed, the bacteriocin nisin has been used as an effective biopreservative in some dairy products for decades, while a number of more recently discovered bacteriocins, such as lacticin 3147, demonstrate increasing potential in a number of food applications. Both of these lactococcal bacteriocins belong to the lantibiotic family of posttranslationally modified bacteriocins that contain lanthionine, $\beta$-methyllanthionine and dehydrated amino acids. The exploitation of such naturally produced antagonists holds tremendous potential for extension of shelf-life and improvement of safety of a variety of foods.
\end{abstract}

(c) 2002 Elsevier Science B.V. All rights reserved.

Keywords: Fermentation; Preservation; Bacteriocins; Lacticin 3147; Nisin

\section{Historical perspective}

Modern food processing is dependent on a range of preservative technologies to ensure that food is maintained at an acceptable level of quality from the time of manufacture through to the time of consumption. One of the oldest of these technologies is fermentation, a process dependent on the biological activity of

\footnotetext{
${ }^{*}$ Corresponding author. Tel.: +353-25-42229; fax: +353-2542340 .

E-mail address: pross@moorepark.teagasc.ie (R. Paul Ross).
}

microorganisms for production of a range of metabolites which can suppress the growth and survival of undesirable microflora in foodstuffs. Fermentation as a food preservation technique can be traced back thousands of years (Fig. 1). Indeed, it is thought that the art of cheese-making was developed as far back as 8000 years ago in the fertile Cresent between Tigris and the Euphrates rivers in Iraq, at a time when plants and animals were just being domesticated (Fox, 1993). Later, alcoholic fermentations involved in winemaking and brewing are thought to have been developed during the period $2000-4000 \mathrm{BC}$ by the Egyptians and Sumerians. The Egyptians also devel- 


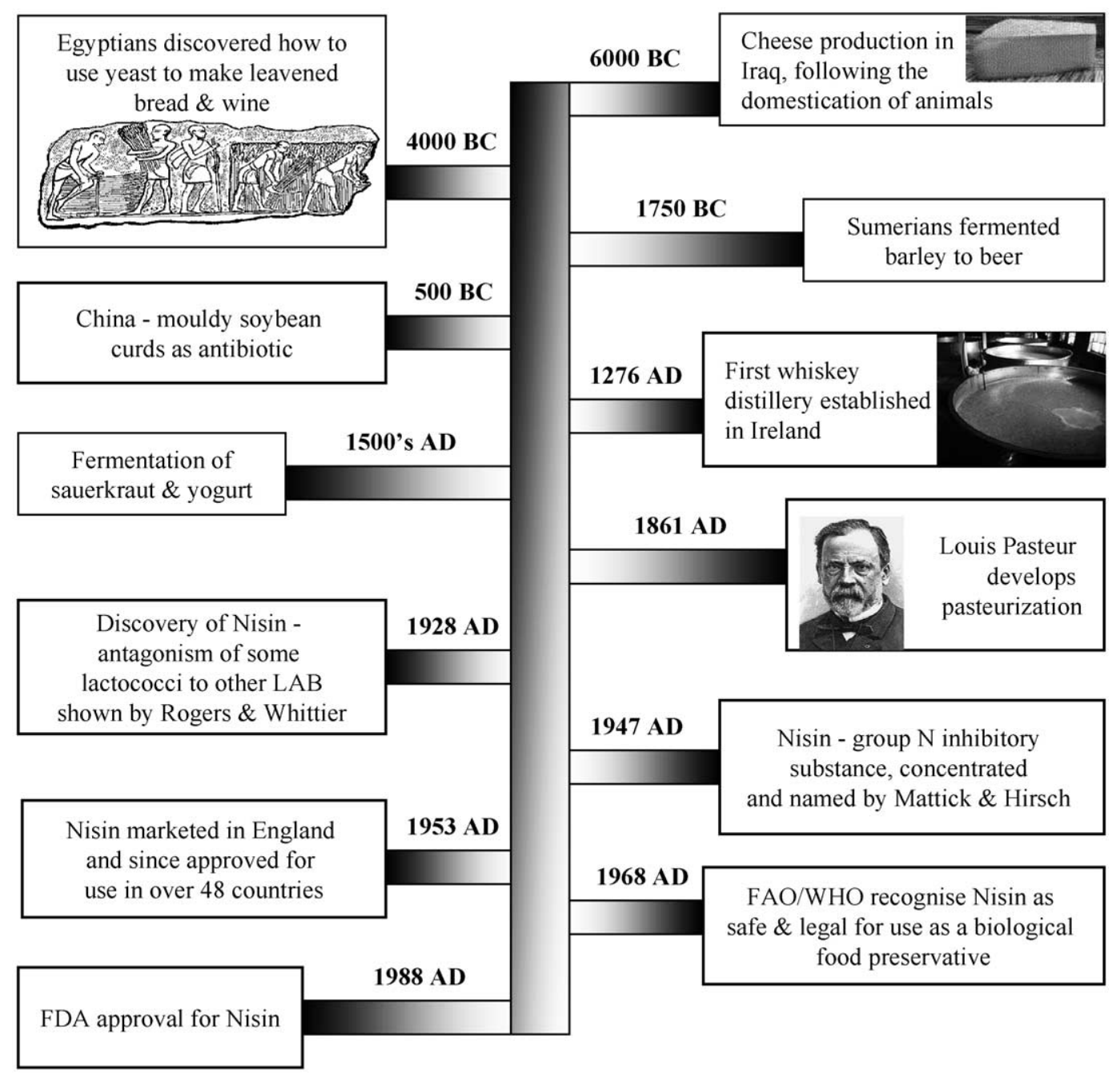

Fig. 1. Major events in food fermentation and preservation through the years.

oped dough fermentations used in the production of leavened bread. Although fermentations have been exploited as a method for the preservation of food and beverages for thousands of years, it has only been in the more recent past that microorganisms were recognized as being responsible for the fermentation process. Pasteurization was developed (1861 AD) and for the first time, the essential role of microorganisms in the fermentation process was realized. Coincidentally, this was the time of the industrial revolution and resulted in the concomitant concentration of populations in large cities. There was therefore a dramatic shift from food production for local communities to large scale food production, necessary to meet the requirements of expanding and more distant markets. This in turn led to the development of large scale fermentation processes for commercial production of fermented foods and alcoholic beverages, with the most widely used microorganisms including yeast for the production of beer, wine and spirits, and lactic acid bacteria (LAB) for a variety of dairy, vegetable and meat fermentations. In each case, the food or beverage raw material provides the substrates for the formation of a range of microbial metabolites that contribute to the shelf-life extension and quality of the product (Table 1). Modern, large-scale production of 
Table 1

Biopreservation by lactic acid bacteria

\begin{tabular}{|c|c|c|}
\hline Product & Microorganisms & Substrate \\
\hline Wine, beer & Saccharomyces cerevisiae, LAB & grapes, grain, hops \\
\hline Bread & Saccharomyces cerevisiae, LAB & wheat, rye, grains \\
\hline Cheddar cheese & Lactococcus (cremoris, lactis) and leuconostoc & milk \\
\hline Swiss-type cheese & Lactobacillus (delbruckii, bulgaricus, helveticus) & milk \\
\hline $\begin{array}{l}\text { Mould- and } \\
\text { smear-ripened cheeses }\end{array}$ & Carnobacterium piscicola, Brevibacterium linens & milk \\
\hline Yogurts & St. thermophilus and Lb. bulgaricus & milk \\
\hline Kefir & Lactococci, yeast, Lb. kefir (and others) & milk \\
\hline $\begin{array}{l}\text { Fermented meats } \\
\quad(<\text { chicken })\end{array}$ & Pediococci, Staphylococci, various LAB & pork, beef \\
\hline Sauerkraut & $\begin{array}{l}\text { L. lactis, Leuc. mesent., Lactobacillus } \\
\text { (brevis, plantarum, curvatus, sake) }\end{array}$ & cabbage \\
\hline Soy sauce & $\begin{array}{l}\text { Aspergillus oryzae/soyae, lactobacilli } \\
\text { and Zygosaccharomyces rouxii }\end{array}$ & soy beans and wheat \\
\hline Vegetables & $\begin{array}{l}\text { Enterococcus (mundtii, faecium), } \\
\text { Lactococcus (cremoris, lactis), } \\
\text { Lactobacillus (plantarum, casei) }\end{array}$ & vegetables \\
\hline Fish & Carnobacterium (piscicola, divergens) & fish \\
\hline
\end{tabular}

Sources: Caplice and Fitzgerald (1999) and Cleveland et al. (2001).

fermented foods and beverages is dependent almost entirely on the use of defined strain starters which have replaced the undefined strain mixtures traditionally used for the manufacture of these products. This switch to defined strains has meant that both culture performance and product quality and consistency have been dramatically improved, while it has also meant that a smaller number of strains are intensively used and relied upon by the food and beverage industries. This intensive use of specific starters has, however, some drawbacks and can lead to production problems resulting in unsatisfactory strain performance. In the case of lactococcal fermentations, bacteriophage proliferation can affect cheese starter performance (Klaenhammer and Fitzgerald, 1994).

For the purposes of this review, the link between fermentation and preservation is biopreservation which refers to the extension of the shelf-life and improvement of the safety of food using microorganisms and/or their metabolites. In this respect, it is well known that starter microorganisms can produce a wide range of antimicrobial compounds and proteinaceous substances which can inhibit or reduce undesirable flora in food products. Indeed, there are many examples which report the inhibition of spoilage and pathogenic bacteria by LAB (Kao and Frazier; 1966; Price and Lee, 1970; Klaenhammer, 1988; Holzapfel et al., 1995). In a study by Daly et al. (1970), the foodborne pathogens Pseudomonas fluorescens, Staphylococcus aureus and Clostridium perfringens were inhibited when co-cultured with a Streptococcus diacetylactis strain. In this case, the $S$. aureus numbers were reduced by more than $99 \%$ in foods such as ham sandwich spread, chicken gravy and ground beef. This inhibition was most likely a direct result of acid production by the starter L. lactis subsp. lactis biovar. diacetylactis strain.

Microorganisms can also produce a range of antimicrobial peptides and proteins which are collectively referred to as bacteriocins. In particular, almost all the different species which make up the LAB group have been reported to produce these inhibitory proteins. The first observations that led to the discovery of bacteriocins were made by Rogers and Whittier (1928) in England when they discovered that certain lactococcal strains had an inhibitory effect on the growth of other LAB. Shortly after, researchers in New Zealand (Whitehead, 1933) observed similar inhibition of cheese starter cultures and isolated and identified the active antimicrobial as being proteinaceous in nature. Because the producing strains were identified as lactic streptococci of the serological group N, this bacteriocin was called 'nisin' or group $\mathrm{N}$ inhibitory substance (Mattick and Hirsch, 1947). 
The bacteriocin was first marketed in England in 1953 and since then has been approved for use in over 48 countries. Significantly, nisin was assessed to be safe for food use by the Joint Food and Agriculture Organization/World Health Organization (FAO/ WHO) Expert Committee on Food Additives in 1969. The FAO/WHO Codex Committee on milk and milk products accepted nisin as a food additive for processed cheese at a concentration of $12.5-\mathrm{mg}$ pure nisin per kilogram product. This biopreservative was also added to the European food additive list where it was assigned the number E234 (EEC, 1983). Although the use of nisin is still restricted mainly to its exploitation for the prevention of clostridial growth in processed cheese, dairy desserts and cheese spreads, the potential fields of opportunity continue to grow in both food and biomedical applications (Ryan et al., 2002).

\section{Food fermentation by LAB}

As stated above, food fermentations have been practiced for millennia with the result that there is a tremendous variety of fermented foods ranging from those derived from meat and plants to those derived from milk and dairy products. In each case, the fermentation process involves the oxidation of carbohydrates to generate a range of products which are principally organic acids, alcohol and carbon dioxide (Ray and Daeschel, 1992). Such products have a preservative effect through limiting the growth of spoilage and/or pathogenic flora in the food product. In addition, a number of desirable products, which affect the quality of the food may be produced, including the flavour compounds diacetyl and acetaldehyde, as well as compounds which may have positive health implications such as vitamins, antioxidants and bioactive peptides. When considering food fermentations (as distinct from alcoholic fermentations involving yeast), a group of bacteria known collectively as the LAB is primarily responsible for many of the microbial transformations found in the more common fermented food products (Table 1). This group is composed of a number of genera including Lactoctoccus, Lactobacillus, Enterococcus, Streptococcus, Leuconostoc and Pediococcus and generally produces lactic acid as their major end product. They are strictly fermentative and lack the ability to synthesize haeme which means that they are consequently catalase-negative and lack a terminal electron transport chain (Condon, 1987). The most common members of the group which are exploited for food uses include lactocococci for cheese manufacture, Streptococcus salivarius subsp. thermophilus for cheese and yoghurt manufacture and various members of the Lactobacillus genus for a variety of dairy, meat and vegetable fermentations (Table 1). Members of the LAB can be subdivided into two distinct groups based on their carbohydrate metabolism. The homofermentative group composing Lactocococcus, Pediococcus, Enterococcus, Streptococcus and some lactobacilli use the Embden-MeyerhofParnas pathway to convert $1 \mathrm{~mol}$ of glucose into $2 \mathrm{~mol}$ of lactate. In contrast, heterofermentative bacteria produce equimolar amounts of lactate, $\mathrm{CO}_{2}$ and ethanol from glucose using the hexose monophosphate or pentose pathway, and in so doing generate only half the energy of the homofermentative group. Members of this group include Leuconostoc, Weissella and some lactobacilli. Although enterococci are commonly found in artisenal fermentations and are a component of some mixed starters, their deliberate addition to food is somewhat controversial, given that members of the genus are known human pathogens, and are a significant cause of hospital-acquired and urinary tract infections (Franz et al., 1999). In addition, from a genetic standpoint, enterococci may contribute to the spread of antibiotic resistance genes, given that many strains contain multiple resistances, some of which are encoded on transmissible plasmids (Clewell, 1990).

\section{Antimicrobial compounds produced by LAB}

The preservative action of starter strains in food and beverage systems is attributed to the combined action of a range of antimicrobial metabolites produced during the fermentation process (de Vuyst and Vandamme, 1994a; Caplice and Fitzgerald, 1999). These include many organic acids such as lactic, acetic and propionic acids produced as end products which provide an acidic environment unfavourable for the growth of many pathogenic and spoilage microorganisms. Acids are generally thought to exert their 
antimicrobial effect by interfering with the maintenance of cell membrane potential, inhibiting active transport, reducing intracellular $\mathrm{pH}$ and inhibiting a variety of metabolic functions (Doores, 1993). They have a very broad mode of action and inhibit both Gram-positive and Gram-negative bacteria as well as yeast and moulds (Blom and Mortvedt, 1991; Caplice and Fitzgerald, 1999). One good example is propionic acid produced by propionic acid bacteria, which has formed the basis for some biopreservative products, given its antimicrobial action against microorganisms including yeast and moulds. Microgard ${ }^{\text {TM }}$ is a Food and Drug Administration (FDA)-approved fermentate produced by Propionibacterium freudenreichii subsp. shermanii which contains propionic acid and is used in an estimated $30 \%$ of the cottage cheese manufactured in the United States (Daeschel, 1989). In addition to acids, starter strains can produce a range of other antimicrobial metabolites such as ethanol from the heterofermentative pathway, $\mathrm{H}_{2} \mathrm{O}_{2}$ produced during aerobic growth and diacetyl which is generated from excess pyruvate coming from citrate (Ray and Daeschel, 1992). In particular, $\mathrm{H}_{2} \mathrm{O}_{2}$ can have a strong oxidizing effect on membrane lipids and cellular proteins and is produced using such enzymes as the flavo protein oxidoreductases NADH peroxidase, NADH oxidase and $\alpha$-glycerophosphate oxidase (Condon, 1987). Obviously, each antimicrobial compound produced during fermentation provides an additional hurdle for pathogens and spoilage bacteria to overcome before they can survive and/or proliferate in a food or beverage, from time of manufacture to time of consumption. Since any microorganism may produce a number of inhibitory substances, its antimicrobial potential is defined by the collective action of its metabolic products on undesirable bacteria.

Other examples of secondary metabolites produced by LAB which have antagonistic activity include the compound reuterin (Axelsson et al., 1989; Chung et al., 1989; Talarico and Dobrogosz, 1989) and the recently discovered antibiotic reuterocyclin (Ganzle et al., 2000; Holtzel et al., 2000), both of which are produced by strains of Lactobacillus reuteri. Reuterin is an equilibrium mixture of monomeric, hydrated monomeric and cyclic dimeric forms of $\beta$-hydroxypropionaldehyde. It has a broad spectrum of activity and inhibits fungi, protozoa and a wide range of bacteria including both Gram-positive and Gram-neg- ative microorganisms. This compound is produced by stationary phase cultures during anaerobic growth on a mixture of glucose and glycerol or glyceraldehyde. Consequently, in order to use reuterin-producing $L$. reuteri for biopreservation in a food product, it would be beneficial to include glycerol with the strain. This approach was used to extend the shelf-life of herring fillets stored at $5{ }^{\circ} \mathrm{C}$ and involved dipping the fish in a solution containing $1 \times 10^{9} \mathrm{cfu} / \mathrm{ml}$ of $L$. reuteri and 250 mM glycerol (Lindgren and Dobrogosz, 1990). Results demonstrated that after 6-day of storage, there were approximately 100 -fold-less Gram-negative bacteria in the $L$. reuteri samples than in the untreated control.

More recently, the first antibiotic produced by a LAB was discovered (Ganzle et al., 2000; Holtzel et al., 2000). Reuterocyclin is a negatively charged, highly hydrophobic antagonist, and structural elucidation revealed it to be a novel tetramic acid. The spectrum of inhibition of the antibiotic is confined to Grampositive bacteria including Lactobacillus spp., Bacillus subtilis, B. cereus, E. faecalis, S. aureus and Listeria innocua. Interestingly, inhibition of E. coli and Salmonella is observed under conditions that disrupt the outer membrane, including truncated LPS, low $\mathrm{pH}$ and high salt concentrations. Since it is well known that nisin can kill Gram-negative bacteria under conditions which disturb the outer membrane (Stevens et al., 1992), it is likely that there are similarities in the mode of action of nisin and this novel antibiotic.

\section{Bacteriocins produced by LAB}

It has been known for some time that many members of the LAB produce proteinaceous inhibitors referred to collectively as bacteriocins. These inhibitors generally act through depolarization of the target cell membrane or through inhibition of cell wall synthesis (Abee et al., 1995), and range in specificity from a narrow spectrum of activity (lactococcins which only inhibit lactococci) to those which have a broad range of activity such as the lantibiotic nisin (De Vuyst and Vandamme, 1994b; Jack et al., 1995). These proteinaceous inhibitors have attracted an intensive research interest over the last three decades, resulting in the discovery and characterization of many different types of bacteriocins from LAB. Given their current use and potential for biopreservation, the 
remainder of this review will focus on bacteriocins with particular reference to nisin and lacticin 3147. Bacteriocins can be divided into three main groups as follows, based on the groupings proposed by Klaenhammer (1993).

\subsection{Class I: the lantibiotic family}

These are generally small bacteriocins composed of one or two peptides of approximately $3 \mathrm{kDa}$. An unusual feature of this group is that they are posttranslationally modified to contain lanthionine, $\beta$ methyllanthionine and dehydrated amino acids, while at least two members of the group also contain Dalanine (Skaugen et al., 1994; Ryan et al., 1999). This latter amino acid residue is derived from dehydroalanine resulting from the dehydration of a serine residue. Nisin and lacticin 3147 both belong to the lantibiotic family and inhibit a broad range of Grampositive bacteria (De Vuyst and Vandamme, 1994b; Ryan et al., 1996). The lantibiotics were originally subdivided into two groups, A and B (Jung, 1991; Sahl and Bierbaum, 1998). Type A includes the elongated flexible molecules that have a positive charge and act via membrane depolarization, such as nisin. Type B lantibiotics are globular in structure and interfere with cellular enzymatic reactions and examples include mersacidin and actagardine. In addition, some members of the lantibiotic family (e.g. lacticin 3147) require two separate peptides for activity. The continual discovery of extra members of this complex group of peptides has meant that their classification has to be periodically updated (Sahl and Bierbaum, 1998; Guder et al., 2000). On the basis of alignment of mature peptides, we have recently subdivided the lantibiotic peptides from LAB into six subgroups (Twomey et al., in press) as follows: nisin A and nisin $\mathrm{Z}$ make up a single group as they do not share significant homology to any of the other members. The second group is the lacticin 481 group and is made up of just two members, lacticin 481 (Piard et al., 1992; Rince et al., 1994) and lacticin J49 (Hout et al., 1996). The third group, called the mersacidin group, is composed of plantaricin C (Turner et al., 1999), LtnA1 (one component of the two-peptide lacticin 3147) (Ryan et al., 1999) and Plwa (Holo et al., 2001). A fourth group is characterized by LtnA2 (the second component of lacticin 3147) and is composed of itself and Plw $\beta$ (Holo et al., 2001). Finally, the two peptides, $\mathrm{CylL}_{1}$ and $\mathrm{CylL}_{\mathrm{s}}$, from the two-peptide cytolysin (Gilmore et al., 1994), form a group of their own, while lactocin S (Mortvedt et al., 1991) is also grouped separately.

\subsection{Class II: small non-modified peptides}

These are generally small unmodified peptides of $<5 \mathrm{kDa}$, which are subdivided into two groupings. The first (Class IIa) are the Listeria active peptides which are characterized by a YGNGV N-terminus. They are synthesized with a leader peptide attached which is removed by proteolytic processing, usually after a double glycine residue, with examples including bacteriocins such as pediocin PA-1 (Henderson et al., 1992) and sakacin A (Holck et al., 1992). However, some Class II bacteriocins (e.g. acidocin B, Leer et al., 1995) use the sec system for secretion. As in the lantibiotic family, some Class II bacteriocins are composed of two separate peptides and are referred to as the Class IIb type. These two-component nonmodified bacteriocins include lacticin F (Muriana and Klaenhammer, 1991) and lactococcin G (NissenMeyer et al., 1992).

\subsection{Class III: large heat-labile proteins}

The class III bacteriocins are the least well-characterized group and consist of heat-labile proteins which are generally $>30 \mathrm{kDa}$. The group includes Helvetin J produced by Lactobacillus helveticus (Joerger and Klaenhammer, 1986) and enterolysin produced by Enterococcus faecium (Nilson, 1999).

\section{Nisin-structure, function and genetics}

Nisin is undoubtedly the most well known and characterized bacteriocin and the only one to have realized widespread commercial use. This bacteriocin has consequently been the subject of a wide variety of fundamental studies as to its structure and genetics, and the reader is directed to a number of review articles and references therein (De Vuyst and Vandamme, 1994b; Dutton et al., 2002). Nisin is composed of 34 amino acids and has a pentacyclic structure (Gross and Morell, 1971; Shiba et al., 
1991) with one lanthionine residue (ring A) and four $\beta$-methyllanthionine residues (rings $\mathrm{B}, \mathrm{C}, \mathrm{D}$ and $\mathrm{E}$ ). A natural variant of nisin, nisin $\mathrm{Z}$ exists in which the histidine at position 27 is replaced by asparagine (Kuipers et al., 1991; Mulders et al., 1991). This variant has been reported to have improved solubility over nisin at higher $\mathrm{pH}$ values. An interesting feature of nisin is its unusually high specific activity when compared to eukaryotic-derived peptides such as meganin. Nisin can be effective at nanomolar concentrations depending on the target strain under investigation, while the eukaryotic peptide meganin is generally up to 1000 -fold less active. Earlier studies with nisin demonstrated that it inhibited peptidoglycan biosynthesis (Linnet and Strominger, 1973) and that it interacted with either lipid I or lipid II (Reisinger et al., 1980). It was later found that nisin caused pore formation in the membranes of sensitive bacteria (Ruhr and Sahl, 1985; Sahl et al., 1987; Benz et al., 1991). More recently, it was shown that nisin interacts with a docking molecule, lipid II, which is a membrane-bound precursor for cell wall biosynthesis (Fig. 2). Indeed, in the absence of this precursor, significantly higher concentrations of nisin are required to form pores (Breukink et al., 1999; Wiedemann et al., 2001). Significantly, mutations in the N-terminal rings of nisin indicated that these are involved in lipid II binding, whereas mutations in the flexible hinge region severely affected the ability of the bacteriocin to form pores. Such experiments have revealed the dual functionality of the nisin molecule involving initial binding to lipid II followed by pore formation resulting in rapid killing of the target cell.
A number of genes are involved in the production and export of nisin as well as immunity (Rodriguez and Dodd, 1996). These genes are tightly linked together in the nisin cluster made up of a total of 11 genes of which nis $A$ encodes the nisin precursor itself. Interestingly, the genes responsible for nisin A production and immunity are carried on a $70-\mathrm{kb}$ conjugative transposon called Tn5301 from L. lactis NCFB894 (Dodd et al., 1990; Horn et al., 1991) or Tn5276 from L. lactis NIZO R5 (Rauch and De Vos, 1992), while the genetic determinants for nisin $Z$ are on the transposon Tn5278 (Immonen et al., 1995). These transposons also encode sucrose utilization genes $\operatorname{sac} A, \operatorname{sacB}$ and $s a c R$. Nisin synthesis is regulated by a two-component regulatory system made up of the membrane-bound histidine kinase sensor protein NisK and the regulator NisR. This regulatory system responds to extracellular nisin, which leads to the expression of genes involved in immunity and synthesis/posttranslational modification (Kuipers et al., 1995). Indeed, this regulatory system is the basis for the nisin-induced controlled expression system (NICE) which is a very useful overexpression system for heterologous expression of proteins in many Gram-positive bacteria (De Vos, 1999).

\section{Lacticin 3147-structure, function and genetics}

Although the bacteriocin lacticin 3147 is not commercially exploited at present, its many potential applications make it a suitable example to select, from the many recently discovered bacteriocins, for inclu-

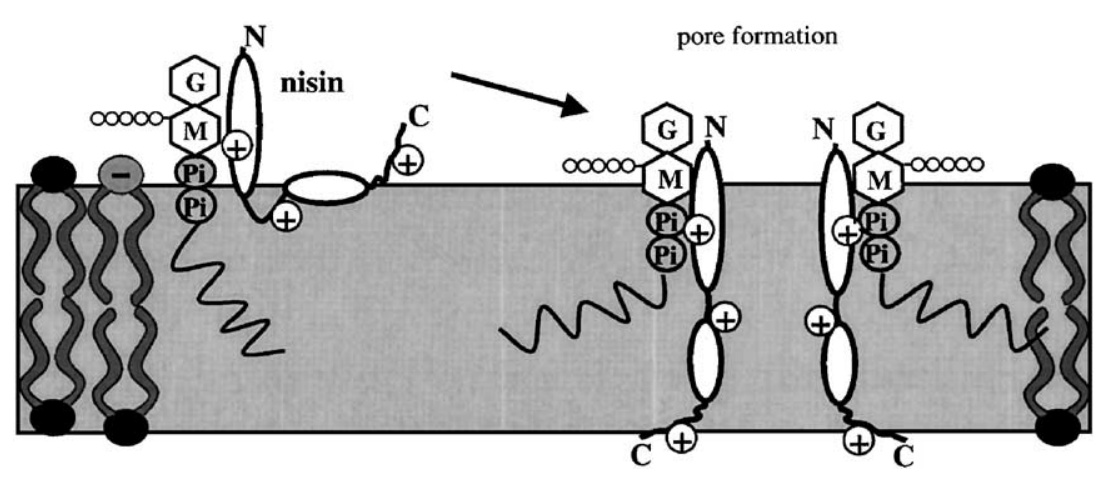

Fig. 2. A schematic representation of the mode of action of nisin (reproduced with kind permission of Wiedemann et al., 2001). 
sion in this review. Lacticin 3147 is a broad spectrum bacteriocin produced by a Lactococcus lactis strain that was originally isolated from an Irish kefir grain (Ryan et al., 1996). This bacteriocin has been the main focus of our research for the last 7 years from both fundamental science and applied aspects. The bacteriocin is composed of two similarly sized posttranslationally modified peptides, both of which are required from optimal killing activity (Ryan et al., 1999). The bacteriocin causes pore formation in target cells which selectively causes release of $\mathrm{K}^{+}$ions and inorganic phosphate (McAuliffe et al., 1998). An unusual feature of these lanthionine-containing peptides is that both also contain D-alanine, the biological significance of which is not understood in this context (Ryan et al., 1999). Recent results have demonstrated that these unusual peptides act sequentially on target cells and at nanomolar concentrations (unpublished results). The bacteriocin has a very broad spectrum of action that includes all Gram-positive bacteria tested including food pathogens such as Listeria monocytogenes and $S$. aureus and food spoilage microorganisms such as Clostridium tyrobutyricum (Ryan et al., 1996; Galvin et al., 1999). The activity of lacticin 3147 suggests that this bacteriocin has potential in a wide range of applications spanning food safety to use in the treatment or prevention of human and animal infections.

An attractive feature associated with lacticin 3147 is that the genetic determinants associated with the bacteriocin are encoded on a 60 -kb self-transmissible plasmid pMRC01 which has been completely sequenced (Dougherty et al., 1998). This plasmid can readily be transferred to a lactose-deficient lactococcal host L. lactis MG1363 at relatively high frequencies (up to $10^{-2}-10^{-3}$ per donor) using lacticin 3147 itself for selection. Using the resultant strain as a donor, the genetic determinants have been transferred to greater than 25 different lactococcal hosts, many of which are commonly used lactococcal starters in the cheese industry (Fig. 3; Coakley et al., 1997; O'Sullivan et al., 1998; Fenelon et al., 1999). All of these transconjugants now produce the bacteriocin and can potentially be substituted for the parent strain in different commercial applications. In some cases, the entire plasmid was not transferred to some of these strains but instead the lacticin genes had integrated into a resident plasmid.

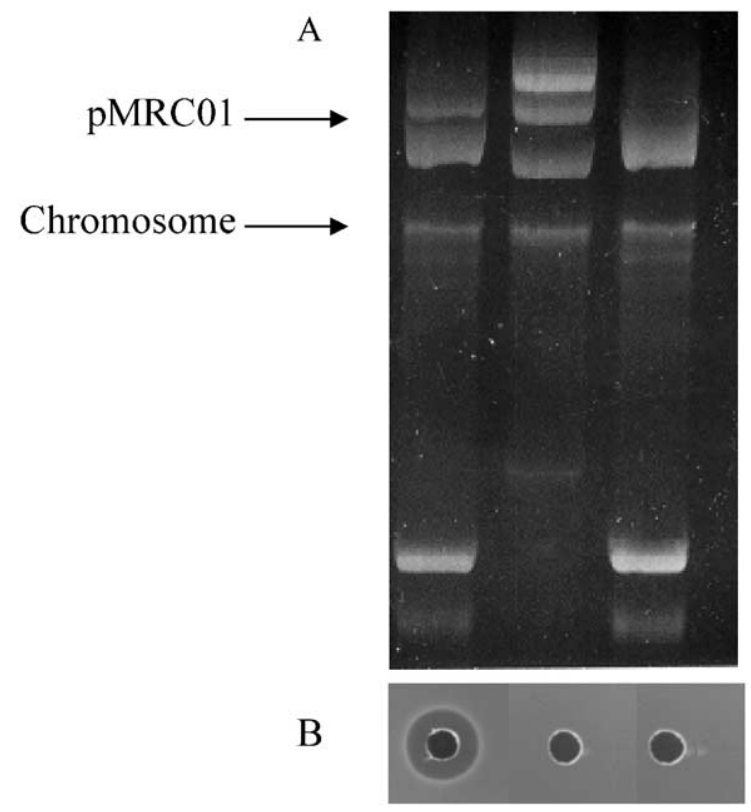

Fig. 3. (A) Plasmid profile of L. lactis HP (lane 3) to demonstrate the acquisition of pMRC 01 by transconjugants (lane 1). The position of the chromosome and pMRC01 is indicated by horizontal arrows. Plasmids isolated from L. lactis DRC3 (lane 2) were used as standard molecular weight sizes $(78,65$ and $58 \mathrm{~kb})$. (B) Well diffusion assay showing zones of inhibition whenever pMRC01 is present, demonstrating that lacticin 3147 is being produced.

To facilitate the detailed genetic analysis of the lacticin genes, the entire region encoding the bacteriocin $(12.6 \mathrm{~kb})$ was cloned into the lactococcal vector pCI372. In all, 10 genes are included in this region and are expressed from divergent promoters which control two clusters namely $\operatorname{ltn} A_{1} A_{2} M_{1} T M_{2} D$ and ltnRIFE. The putative functions of some of these genes have, in many cases, been confirmed using a series of knockout deletions in single or multiple genes of the cluster. For example, the inactivation of either of the structural genes $\operatorname{ltn} A_{1}$ or $\operatorname{ltn} A_{2}$ resulted in strains which were unable to produce bacteriocin, however, when the supernatants from each of these cultures were combined, active bacteriocin resulted. Similar phenotypic results were obtained when supernatants from strains in which the modification genes $l t n M_{1}$ and $l t n M_{2}$ were combined (McAuliffe et al., 2000a). Further subcloning of this region revealed that the smaller of the two clusters (ltnRIFE) confers 
immunity to the bacteriocin. LtnI encodes a 116 amino acid protein with a predicted membrane location and bears no homology to other bacteriocin immunity proteins (McAuliffe et al., 2000b). However, when cloned into the expression plasmid pMG36e, this gene was associated with a level of immunity to lacticin 3147 similar to that obtained with the parent plasmid pMRC01. This gene has potential as a food grade selectable marker for lactococci where studies have demonstrated that it is comparable to the CAT gene for selection of electroporatants. Regulation of the lacticin 3147 gene cluster also has some interesting features (McAuliffe et al., 2001). For example, while the promoter controlling biosynthesis $\left(\mathrm{P}_{\mathrm{bac}}\right)$ appears to be constitutive, characterization of a downstream region revealed a stem loop structure within the ltnMl gene which probably acts as rho-independent terminator that functions as a signal for processing of the $\ln A_{1} A_{2} M_{1} T M_{2} D$ transcript. In addition, the promoter of the linRIFE operon $\left(\mathrm{P}_{\mathrm{imm}}\right)$ was shown to be regulated by the repressor LtnR.

\section{Applications of bacteriocins as biopreservatives}

There is a significant dilemma at present in modern food processing in that there is an expectation for long shelf-life and safety of foods and beverages, at a time when consumer preferences are veering towards foods which are minimally processed and free from chemical preservatives (due to safety concerns). Consequently, there has been renewed interest in so-called "green technologies" including novel approaches for minimal processing and the exploitation of microbial metabolites such as bacteriocins for biopreservation. Undoubtedly, the most well-known and studied bacteriocin is nisin, the lantibiotic which has found application as a shelf-life extender in a broad range of dairy and nondairy products worldwide, ranging from processed and cottage cheese to dairy desserts and liquid egg (De Vuyst and Vandamme, 1994b). The bacteriocin was also found to be effective in such applications as inhibiting spoilage bacteria during beer and wine fermentations, while the exploitation of nisin-producing strains has been shown to improve certain vegetable fermentations. The success of nisin has prompted many research groups to search for novel bacteriocin-producing strains over the last 20 years. This has resulted in a growing arsenal of potential biopreservatives which may be used either singularly or in combination to protect food from spoilage and safety problems. These biopreservatives can be used in a number of ways in food systems from the use of the bacteriocin-producing strains directly in food as starter or protection cultures to the use of concentrated bacteriocin preparations as food additives in food systems.

\section{Nisin as a biopreservative}

Since nisin is produced by a lactococcal culture, one of the principal applications of nisin-producing strains is in the manufacture of cheese, where it has been investigated for the inhibition of both spoilage and pathogenic microorganisms. From a food safety point of view, the pathogen of primary concern in a number of cheeses is L. monocytogenes, which is capable of growing at refrigeration temperatures (Farber and Peterkin, 1991) and has the ability to survive the acidic conditions of cheese manufacture (Seelinger and Jones, 1986). Moreover, the pathogen can also resume growth in cheeses exhibiting a $\mathrm{pH}$ rise during ripening, such as on the surface of mould-ripened cheese. Furthermore, Listeria has been shown to survive the manufacturing process of cottage cheese, Camembert and Cheddar (Doyle et al., 1987). Indeed, listeriosis outbreaks linked to the consumption of contaminated dairy products are well documented (Linnan et al., 1988). A number of studies have been performed with both nisin-producing cultures and Nisaplin ${ }^{\circledR}$, demonstrating the effectiveness of nisin for the inhibition of L. monocytogenes in cheese (Maisnier-Patin et al., 1992; Ferreira and Lund, 1996). An example of the effectiveness of nisin is given in Fig. 4, where the presence of nisin in cottage cheese resulted in inhibition of L. monocytogenes (Benkerroum and Sandine, 1988). Nisin has also been investigated and demonstrated to be effective in a range of food products which include processed cheese and cheese spreads, milk products, canned foods, fish and meat products, brewing, wine manufacture, liquid egg and confectionery. Numerous extensive reviews catalog the many widespread uses of nisin as a 


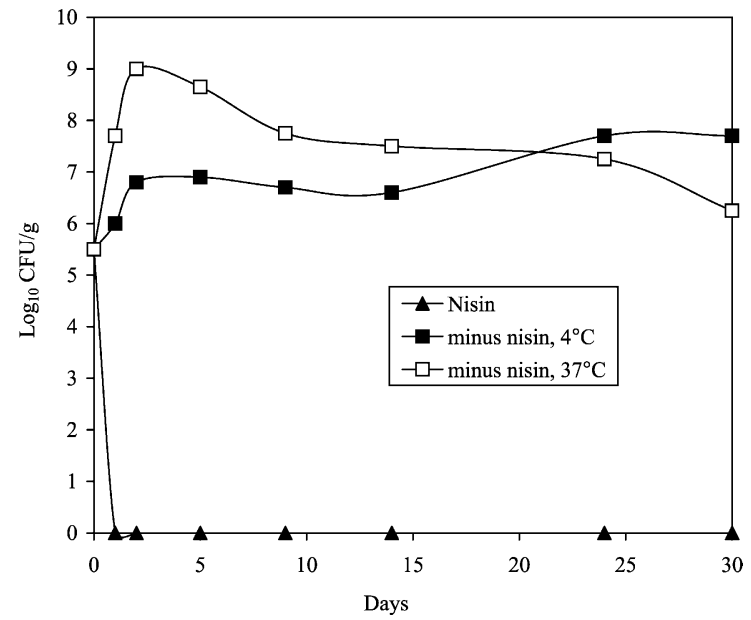

Fig. 4. Growth of L. monocytogenes 7644 at 4 and $37{ }^{\circ} \mathrm{C}$ in the presence and absence of nisin $\left(2.55 \times 10^{3} \mathrm{IU} / \mathrm{g}\right)$ in sterilized cottage cheese (Based on data from Benkerroum and Sandine, 1988).

biopreservative, and the reader is directed to the following examples: Ray and Daeschel (1992), De Vuyst and Vandamme (1994b) and Ryan et al. (2002).

\section{Lacticin 3147 as a biopreservative}

Lacticin 3147 has also been shown to be an effective biopreservative in many food applications (Ross et al., 1999). An important advantage of lacticin 3147 is that many transconjugants have been generated which produce the bacteriocin. Importantly, the performance of these strains in food fermentations is not compromised by the presence of the plasmid. When used for production of Cheddar cheese, use of these starters is associated with reduced (at least 100fold) numbers of nonstarter lactic acid bacteria during cheese ripening (Ryan et al., 1996). Since this microflora is often associated with quality defects in the product, such as crystal formation, flavour defects and slit defects, use of these bacteriocin-producing cultures should offer manufacturers greater predictability in terms of product quality. In an extension of this concept, Lactobacillus strains exhibiting greater resistance to the bacteriocin have now been isolated which can be used as adjuncts to lacticin-producing starters (Ryan et al., 2001). Consequently, it should be possible to isolate lacticin-resistant derivatives of either flavour adjunct or probiotic strains to be used with lacticin-producing starters.

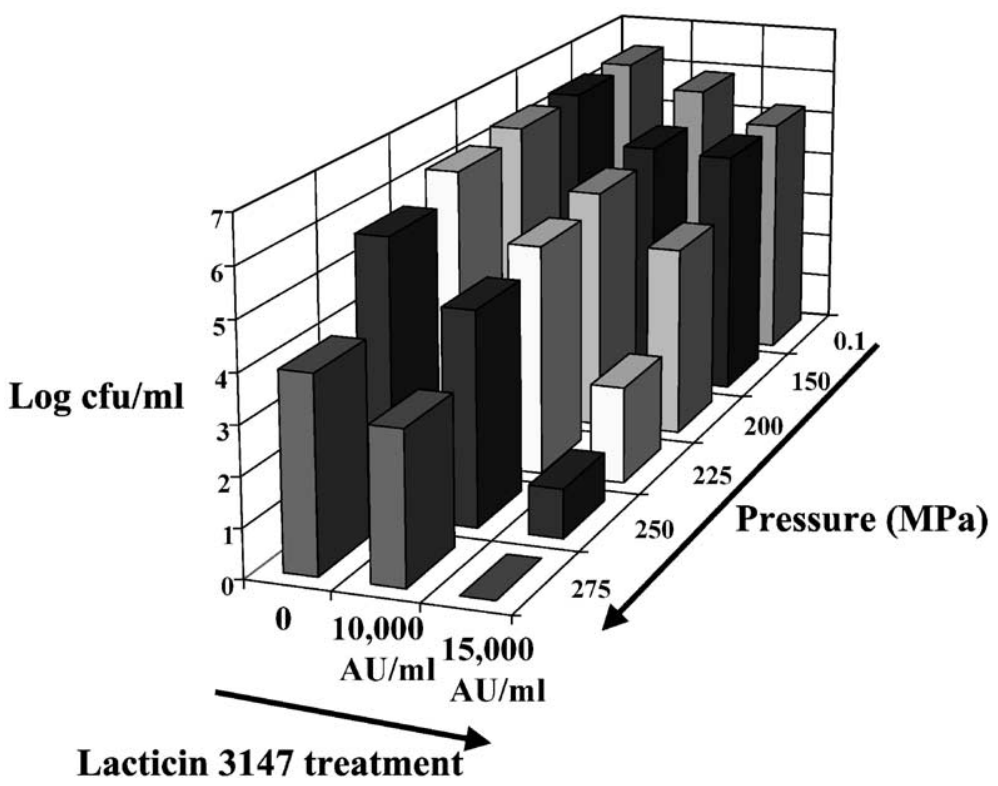

Fig. 5. The effect of high pressure and lacticin 3147 on L. innocua DPC1770 viability (Morgan et al., 2000). 
The exploitation of such bacteriocin-producing cultures can also have a dramatic effect on product safety. For example, use of a lacticin-producing transconjugant resulted in a 5-log reduction in L. monocytogenes numbers over 5 days in a trial where the pathogen was deliberately added to the product during manufacture (McAuliffe et al., 1999). Such trials have also been completed for mould- and smear-ripened cheeses with similar results being obtained in both cases. Like nisin, this bacteriocin can also be used as a biopreservative when added to products as a dried ingredient. Recent trials have shown the efficacy of the dried bacteriocin product in food ranging from infant formula to dried soup (Morgan et al., 1999; Morgan et al., 2001) and fresh pork sausage (Scannell et al., 2000). When lacticin 3147 was combined with high hydrostatic pressure for the inactivation of L. innocua, results demonstrated greater than an additive effect when both treatments were used in combination (Fig. 5; Morgan et al., 2000). Furthermore, preliminary results demonstrate the effectiveness of the bacteriocin for extending the shelf-life of pasteurized milk.

These examples with both nisin and lacticin 3147 as biopreservatives serve to demonstrate the uses which bacteriocins, produced by food-grade bacteria, have to offer for food applications, although full industrial exploitation of newer preservatives such as lacticin 3147 is dependent on legislative approval being obtained in different countries.

\section{Future prospects}

In conclusion, we are now entering the postgenomic age of microbiology at a time when many microorganisms used for food production have already been sequenced. This offers a new knowledge-based approach to the exploitation of bacteria for food production, from metabolic engineering of microorganisms to produce antimicrobials or nutritionals, to the molecular mining of activities as yet unknown but which could benefit food production. In addition, the availability of the genomes of many food pathogenic and spoilage bacteria may open up new possibilities for the design of novel antimicrobials which target essential functions of these problematic bacteria. The real challenge of the genomics era, as it applies to food systems, is the harnessing of this wealth of information for improved culture performance and activities, thereby improving the safety and quality and composition of our food supply.

\section{References}

Abee, T., Krockel, L., Hill, C., 1995. Bacteriocins: modes of action and potentials in food preservation and control of food poisoning. International Journal of Food Microbiology 28, $169-185$.

Axelsson, L.T., Chung, T.C., Dobrogosz, W.J., Lindgren, S.E., 1989. Production of a broad spectrum antimicrobial substance by Lactobacillus reuteri. Microbial Ecology of Health and Disease 2, 131-136.

Benkerroum, N., Sandine, W., 1988. Inhibitory action of nisin against Listeria monocytogenes. Journal of Dairy Science 71, 3237-3245.

Benz, R., Jung, G., Sahl, H.-G., 1991. Mechanism of channel-forming lantibiotics in black lipid membranes. In: Jung, G., Sahl, H.-G. (Eds.), Nisin and Novel Lantibiotics. ESCOM, Leiden, The Netherlands, pp. 359-372.

Blom, H., Mortvedt, C., 1991. Anti-microbial substances produced by food associated micro-organisms. Biochemical Society Transactions 19, 694-698.

Breukink, E., Wiedemann, I., van Kraaij, C., Kuipers, O.P., Sahl, H.-G., de Kruijff, B., 1999. Use of the cell wall precursor lipid II by a pore-forming peptide antibiotic. Science 286, 2361-2364.

Caplice, E., Fitzgerald, G.F., 1999. Food fermentations: role of microorganisms in food production and preservation. International Journal of Food Microbiology 50, 131-149.

Chung, T.C., Alexsson, L., Lindgren, S.E., Dobrogosz, W.J., 1989. In vitro studies on reuterin synthesis in Lactobacillus reuteri. Microbial Ecology of Health and Disease 2, 137-141.

Cleveland, J., Montville, T.J., Nes, I.F., Chikindas, M.L., 2001. Bacteriocins: safe, natural antimicrobials for food preservation. International Journal of Food Microbiology 71, 1-20.

Clewell, D.B., 1990. Moveable genetic elements and antibiotic resistance in enterococci. European Journal of Clinical Microbiology and Infectious Disease 9, 90-102.

Coakley, M., Fitzgerald, G.F., Ross, R.P., 1997. Application and evaluation of phage resistance- and bacteriocin-encoding plasmid pMRCO1 for the improvement of dairy starter cultures. Applied and Environmental Microbiology 63, 1434-1440.

Condon, S., 1987. Responses of lactic acid bacteria to oxygen. FEMS Microbiological Reviews 46, 269-280.

Daeschel, A.M., 1989. Antimicrobial substances from lactic acid bacteria for use as food preservatives. Food Technology 43, 164.

Daly, C., Sandine, W.E., Elliker, P.R., 1970. Interactions of food starter cultures and food-borne pathogens: Streptococcus diacetylactis versus food pathogens. Journal of Milk and Food Technology 35, 349-357.

De Vos, W.M., 1999. Gene expression systems for lactic acid bacteria. Current Opinion in Microbiology 2, 289-295. 
De Vuyst, L., Vandamme, E.J., 1994a. Bacteriocins of lactic acid bacteria. Blackie Academic \& Professional, Glasgow.

De Vuyst, L., Vandamme, E.J., 1994b. In: De Vuyst, L., Vandamme, E.J. (Eds.), Nisin, a lantibiotic produced by Lactococcus lactis subsp. lactis: properties, biosynthesis, fermentation and application. Blackie Academic Press, Glasgow, pp. 151-222.

Dodd, H.M., Horn, N., Gasson, M.J., 1990. Analysis of the genetic determinants for the production of the peptide antibiotic nisin. Journal of General Microbiology 136, 555-566.

Doores, S., 1993. In: Davidson, P.M, Branen, A.L. (Eds.), Organic Acids. Marcel Dekker, New York, pp. 95-136.

Dougherty, B., Hill, C., Weidman, J., Richardson, D.R., Venter, J.C., Ross, R.P., 1998. Sequence and analysis of the $60-\mathrm{kb}$ conjugative, bacteriocin producing plasmid pMRC01 from $\mathrm{Lac}$ tococcus lactis DPC3147. Molecular Microbiology 29, 10291038.

Doyle, M.P., Glass, K.A., Berry, J.Y., Garcia, G.A., Pollard, D.J., Schultz, R.D., 1987. Survival of Listeria monocytogenes in milk during high temperature, short time pasteurization. Applied and Environmental Microbiology 53, 1433-1438.

Dutton, C.J., Haxell, M.A., McAuthur, H.A.I, Wax, R.G., 2002. Peptide Antibiotics, Discovery, Modes of Action and Applications. Marcel Dekker, New York.

EEC, 1983. EEC Commission Directive 83/463/EEC.

Farber, J.M., Peterkin, P.I., 1991. Listeria monocytogenes, a foodborne pathogen. Microbiological Reviews 55, 476-511.

Fenelon, M.A., Ryan, M.P., Rea, M.C., Guinee, T.P., Ross, R.P., Hill, C., Harrington, D., 1999. Elevated temperature ripening of reduced fat cheddar made with or without lacticin 3147-producing starter culture. Journal of Dairy Science 82, 10-22.

Ferreira, M.A.S.S., Lund, B.M., 1996. The effect of nisin on Listeria monocytogenes in culture medium and long-life cottage cheese. Letters in Applied Microbiology 22, 433-438.

Fox, P.F., 1993. Cheese: an overview. In: Fox, P.F. (Ed.), Cheese; Chemistry, Physics and Microbiology. Chapman \& Hall, London, England, pp. 1-36.

Franz, C.M.A.P., Holzapfel, W.H., Styles, M.E., 1999. Enterococci at the crossroads of food safety? International Journal of Food Microbiology 47, 1-24.

Galvin, M., Hill, C., Ross, R.P., 1999. Lacticin 3147 displays activity in buffer against Gram-positive bacterial pathogens which appear insensitive in standard plate assays. Letters in Applied Microbiology 28, 355-358.

Ganzle, M.G, Holtzel, A., Walter, J., Jung, G., Hammes, W.P., 2000. Characterization of reutericyclin produced by Lactobacillus reuteri LTH2584. Applied and Environmental Microbiology 66, $4233-4333$.

Gilmore, M.S., Segarra, R.A., Booth, M.C., Bogie, C.P., Hall, L.R., Clewell, D.B., 1994. Genetic structure of the Enterococcus faecalis plasmid pAD1-encoded cytolytic toxin system and its relationship to lantibiotic determinants. Journal of Bacteriology 176, 7335-7344.

Gross, E., Morell, J.L., 1971. The structure of nisin. Journal of the American Chemical Society 93, 4634-4635.

Guder, A., Wiedemann, I., Sahl, H.-G., 2000. Post-translationally modified bacteriocins - the lantibiotics. Biopolymers 55, 62-73.

Henderson, J.T., Chopko, A.L., Wassenaar, P.D., 1992. Purification and primary structure of pediocin PA-1 produced by Pediococcus acidilactici PAC-1.0. Archives of Biochemistry and Biophysics $295,5-12$.

Holck, A., Axelsson, L., Birkeland, S.E., Aukrust, T., Blom, H., 1992. Purification and amino acid sequence of sakacin A, a bacteriocin from Lactobacillus sake Lb 706. Journal of General Microbiology 138, 2715-2720.

Holo, H., Jeknic, Z., Daeschel, M., Stevanovic, S., Nes, I.F., 2001. Plantaricin W from Lactobacillus plantarum belongs to a new family of two-peptide lantibiotics. Microbiology 147, 643-651.

Holtzel, A., Ganzle, M.G., Nicholson, G.J., Hammes, W.P., Jung, G., 2000. The first low-molecular-weight antibiotic from lactic acid bacteria: reutericyclin, a new tetramic acid. Angewandte Chemie. International Edition 39, 2766-2768.

Holzapfel, W.H., Geisen, R., Schillinger, U., 1995. Biological preservation of foods with reference to protective cultures, bacteriocins and food-grade enzymes. International Journal of Food Microbiology 24, 343-362.

Horn, N., Swindell, S., Dodd, H., Gasson, M.J., 1991. Nisin biosynthesis genes are encoded by a novel conjugative transposon. Molecular and General Genetics 228, 129-135.

Hout, E., Meghrous, J., Barrena-Gonzalez, C., Petitdemange, H., 1996. Bacteriocin J46, a new bacteriocin produced by Lactococcus lactis subsp. cremoris J46: isolation and characterization of the protein and its gene. Anaerobe 2, 137-145.

Immonen, Y., Ye, S., Ra, R., Qiao, M., Paulin, L., Saris, P.E.J., 1995. The codon usage of the nisin $\mathrm{Z}$ operon in Lactococcus lactis N8 suggests a non-lactococcal origin of the conjugative nisin-sucrose transposon. Sequence 5, 203-218.

Jack, R.W., Tagg, J.R., Ray, B., 1995. Bacteriocins of gram positive bacteria. Microbiological Reviews 59, 171-200.

Joerger, M.C., Klaenhammer, T.R., 1986. Characterization and purification of helveticin $\mathrm{J}$ and evidence for a chromosomally determined bacteriocin produced by Lactobacillus helveticus 481. Journal of Bacteriology 167, 439-446.

Jung, G., 1991. Lantibiotics: a survey. In: Jung, G., Sahl, H.-G. (Eds.), Nisin and novel lantibiotics. ESCOM Science Publishers, Leiden, pp. 1-34.

Kao, C.T., Frazier, W.C., 1966. Effect of lactic acid bacteria on growth of Staphylococcus aureus. Applied Microbiology 14, 251-255.

Klaenhammer, T.R., 1988. Bacteriocins of lactic acid bacteria. Biochemie 70, 337-349.

Klaenhammer, T.R., 1993. Genetics of bacteriocins produced by lactic acid bacteria. FEMS Microbiology Reviews 12, 39-86.

Klaenhammer, T.R., Fitzgerald, G.F., 1994. Bacteriophage and bacteriophage resistance. In: Gasson, M.J., de Vos, W.M. (Eds.), Genetics and Biotechnology of Lactic Acid Bacteria. Chapman \& Hall, London, England, pp. 106-168.

Kuipers, O.P., Yap, W.M.G.J., Rollemn, H.S., Beerthuyzen, M.M., Siezen, R.J., De Vos, W.M., 1991. Expression of wild type and mutant nisin genesin Lactococcus lactis. In: Jung, G., Sahl, H.-G. (Eds.), Nisin and Novel Lantibiotics. ESCOM Science Publishers, Leiden, pp. 250-259.

Kuipers, O.P., Beerthuyzen, M.M, de Ruyter, P.G.G.A., Luesink, E.J., de Vos, W.M., 1995. Autoregulation of nisin biosynthesis 
in Lactococcus lactis by signal transduction. Journal of Biological Chemistry 20, 27299-27304.

Leer, R.J., van der Vossen, J.M., van Giezen, M., van Noort, J.M., Pouwels, P.H., 1995. Genetic analysis of acidocin B, a novel bacteriocin produced by Lactobacillus acidophilus. Microbiology $141,1629-1635$.

Lindgren, S.E., Dobrogosz, W.J., 1990. Antagonistic activities of lactic acid bacteria in food and feed fermentations. FEMS Microbiological Reviews 87, 149-163.

Linnan, M.J., Mascola, L., Lou, X.D., Goulrt, V., May, S., Salminen, C., Hird, D., 1988. Epidemic listeriosis associated with Mexican-style cheese. New England Journal of Medicine 319, $823-828$.

Linnet, P.E., Strominger, J.L., 1973. Additional antibiotic inhibitors of peptidoglycan biosynthesis. Antimicrobial Agents and Chemotherapy 4, 231-236.

Maisnier-Patin, S., Deschamps, N., Tatini, S.R., Richard, J., 1992. Inhibition of Listeria monocytogenes in Camembert cheese made with a nisin-producing starter. Le Lait 72, 249-263.

Mattick, A.T.R., Hirsch, A., 1947. Further observations on an inhibitory substance (nisin) from lactic streptococci. Lancet 2, 5-7.

McAuliffe, O., Ryan, M.P., Ross, R.P., Hill, C., Breeuwer, P., Abee, T., 1998. Lacticin 3147 a broad-spectrum bacteriocin which selectively dissipates the membrane potential. Applied and Environmental Microbiology 64, 439-445.

McAuliffe, O., Hill, C., Ross, R.P., 1999. Inhibition of Listeria monocytogenes in cottage cheese manufactured with a lacticin 3147-producing starter culture. Journal of Applied Microbiology $86,251-256$.

McAuliffe, O., Hill, C., Ross, R.P., 2000a. Each peptide of the twocomponent lantibiotic lacticin 3147 requires a separate modification enzyme for activity. Microbiology 146, 2147-2154.

McAuliffe, O., Hill, C., Ross, R.P., 2000b. Identification and overexpression of ltnl, a novel gene which confers immunity to the two-component lantibiotic lacticin 3147. Microbiology 146, $129-138$

McAuliffe, O., O’Keeffe, T., Hill, C., Ross, R.P., 2001. Regulation of immunity of the two-component lantibiotic, lacticin 3147 , by the transcriptional repressor LtnR. Molecular Microbiology 39, 982-993.

Morgan, S.M., Galvin, M., Kelly, J., Ross, R.P., Hill, C., 1999. Development of a lacticin 3147-enriched whey powder with inhibitory activity against foodborne pathogens. Journal of Food Protection 62, 1011-1016.

Morgan, S.M., Ross, R.P., Beresford, T., Hill, C., 2000. Combination of hydrostatic pressure and lacticin 3147 causes increased killing of Staphylococcus and Listeria. Journal of Applied Microbiology $88,414-420$.

Morgan, S.M., Galvin, M., Ross, R.P., Hill, C., 2001. Evaluation of a spray dried lacticin 3147 powder for the control of Listeria monocytogenes and Bacillus cereus in a range of food systems. Letters in Applied Microbiology 33, 387-391.

Mortvedt, C.I., Nissen-Meyer, J., Sletten, K., Nes, I.F., 1991. Purification and amino acid sequence of lactocin $\mathrm{S}$, a bacteriocin produced by Lactobacillus sake L45. Applied and Environmental Microbiology 57, 1829-1834.

Mulders, J.W.M., Boerrigter, I.J., Rollema, H.S., Siezen, R.J., De
Vos, W.M., 1991. Identification and characterization of the lantibiotic nisin Z, a natural nisin variant. European Journal of Biochemistry 201, 581-584.

Muriana, P.M., Klaenhammer, T.R., 1991. Purification and partial characterization of lactacin F, a bacteriocin produced by Lactobacillus acidophilus 11088. Applied and Environmental Microbiology 57, 114-121.

Nilson, T., 1999. Novel enterococcal bacteriocins; optimisation of production, purification, biochemical and genetic characterisation. PhD thesis, Agricultural University of Norway, As, Norway.

Nissen-Meyer, J., Holo, H., Havarstein, L.S., Sletten, K., Nes, I.F., 1992. A novel lactococcal bacteriocin whose activity depends on the complementary action of two peptides. Journal of Bacteriology $174,5686-5692$.

O’Sullivan, D., Coffey, A., Fitzgerald, G.F., Hill, C., Ross, R.P., 1998. Design of a phage-insensitive lactococcal dairy starter via sequential transfer of naturally occurring conjugative plasmids. Applied and Environmental Microbiology 64, 46184622.

Piard, J.-C., Muriana, P.M., Desmazeaud, M.J., Klaenhammer, T.R., 1992. Purification and partial characterization of lacticin 481, a lanthionine-containing bacteriocin produced by Lactococcus lactis subsp. lactis CNRZ481. Applied and Environmental Microbiology 58, 279-284.

Price, R.J., Lee, J.S., 1970. Inhibition of Pseudomonas species by hydrogen peroxide producing lactobacilli. Journal of Milk and Food Technology 33, 13-18.

Rauch, P.J.G., De Vos, W.M., 1992. Characterization of the novel nisin-sucrose conjugative transposon Tn5276 and its integration into Lactococcus lactis. Journal of Bacteriology 174, $1280-1287$.

Ray, B., Daeschel, M., 1992. Food Biopreservatives of Microbial Origin. CRC Press, Florida, USA.

Reisinger, P., Seidel, H., Tschesche, H., Hammes, W.P., 1980. The effect of nisin on murein synthesis. Archives of Microbiology 127, 187-193.

Rince, A., Dufour, A., Le Pogam, S., Thualt, D., Bourgeois, C.M., Le Pennec, J.P., 1994. Cloning, expression and nucleotide sequence of genes involved in production of lactococcin DR, a bacteriocin from Lactococcus lactis. Applied and Environmental Microbiology 60, 1652-1657.

Rodriguez, J.M., Dodd, H.M., 1996. Genetic determinants for the biosynthesis of nisin, a bacteriocin produced by Lactococcus lactis. Microbiologia 12, 61-74.

Rogers, L.A., Whittier, E.D., 1928. Limiting factors in lactic fermentation. Journal of Bacteriology 16, 211-229.

Ross, R.P., Galvin, M., McAuliffe, O., Morgan, S.M., Ryan, M.P., Twomey, D.P., Meaney, W.J., Hill, C., 1999. Developing applications for lactococcal bacteriocins. Antonie van Leeuwenhoek 76, 337-346.

Ruhr, E., Sahl, H.-G., 1985. Mode of action of the peptide antibiotic nisin and influence on the membrane potential of whole cells and on artificial membrane vesicles. Antimicrobial Agents and Chemotherapy 27, 841-845.

Ryan, M.P., Rea, M.C., Hill, C., Ross, R.P., 1996. An application in cheddar cheese manufacture for a strain of Lactococcus lactis 
producing a novel broad spectrum bacteriocin lacticin 3147 . Applied and Environmental Microbiology 62, 612-619.

Ryan, M.P., Jack, R., Josten, W., Sahl, H.-G., Jung, G., Ross, R.P., Hill, C., 1999. Extensive post-translational modification, including a serine to D-alanine conversion, in the two-component lantibiotic, lacticin 3147. Journal of Biological Chemistry 274, 37544-37550.

Ryan, M.P., Ross, R.P., Hill, C., 2001. Strategy for manipulation of cheese flora using combinations of lacticin 3147-producing and -resistant cultures. Applied and Environmental Microbiology 67, 2699-2704.

Ryan, M.P., Hill, C., Ross, R.P., 2002. In: Dutton, C.J., Haxell, M.A., McAuthor, H.A.I., Wax, R.G. (Eds.), Peptide Antibiotics: Discovery, Modes of Action and Applications. Marcel Dekker, New York, pp. 193-242.

Sahl, H.-G., Bierbaum, G., 1998. Lantibiotics: biosynthesis and biological activities of uniquely modified peptides from grampositive bacteria. Annual Review of Microbiology 52, 41-79.

Sahl, H.-G., Kordel, M., Benz, R., 1987. Voltage-dependent depolarization of bacterial membranes and artificial lipid bilayers by the peptide antibiotic nisin. Archives of Microbiology 149, $120-124$.

Scannell, A.G., Ross, R.P., Hill, C., Arendt, E.K., 2000. An effective lacticin biopreservative in fresh pork sausage. Journal of Food Protection 63, 370-375.

Seelinger, H.P.R., Jones, D., 1986. Genus Listeria. In: Sneath, P.H.A. (Ed.), Bergey's Manual of Systematic Bacteriology. Williams and Wilkins, Baltimore, MD, pp. 1235-1245.

Shiba, T., Wakamiya, T., Fukase, K., Ueki, Y., Teshima, T., Nishikawa, M., 1991. Structure of the lanthionine peptide nisin, an- covenin and lanthiopeptin. In: Jung, G., Sahl, H.-G. (Eds.), Nisin and Novel Lantibiotics. ESCOM Science Publishers, Leiden, pp. 113-122.

Skaugen, M., Nissen-Meyer, J., Jung, G., Stevanovic, S., Sletten, K., Abildgaard, C.I.M., Nes, I.F., 1994. In vivo conversion of L-serine to D-alanine in a ribosomally synthesized polypeptide. Journal of Biological Chemistry 269, 27183-27185.

Stevens, K.A., Sheldon, B.W., Klapes, N.A., Klaenhammer, T.R., 1992. Effective treatment conditions on nisin inactivation of Gram negative bacteria. Journal of Food Protection 55, $763-766$.

Talarico, T.L., Dobrogosz, W.J., 1989. Chemical characterization of an antimicrobial substance produced by Lactobacillus reuteri. Antimicrobial Agents and Chemotherapy 33, 674-679.

Turner, D.L., Brennan, L., Meyer, H.H., Lohaus, C., Siethoff, C., Costa, H.S., Gonzalez, B., Santos, H., Suarez, J.E., 1999. Solution structure of plantaricin C, a novel lantibiotic. European Journal of Biochemistry 264, 833-839.

Twomey, D., Ross, R.P., Ryan, M., Meaney, B., Hill, C., 2002. Lantibiotics produced by lactic acid bacteria: structure, function and applications. Antonie van Leeuwenhoek, in press.

Whitehead, H.R., 1933. A substance inhibiting bacterial growth, produced by certain strains of lactic streptococci. Biochemistry Journal 27, 1793-1800.

Wiedemann, I., Breukink, E., van Kraaij, C., Kuipers, O., Bierbaum, G., de Kruijff, B., Sahl, H.-G., 2001. Specific binding of nisin to the peptidoglycan precursor lipid II combines pore formation and the inhibition of cell wall biosynthesis for potent antibiotic activity. Journal of Biological Chemistry 276, 1772-1779. 